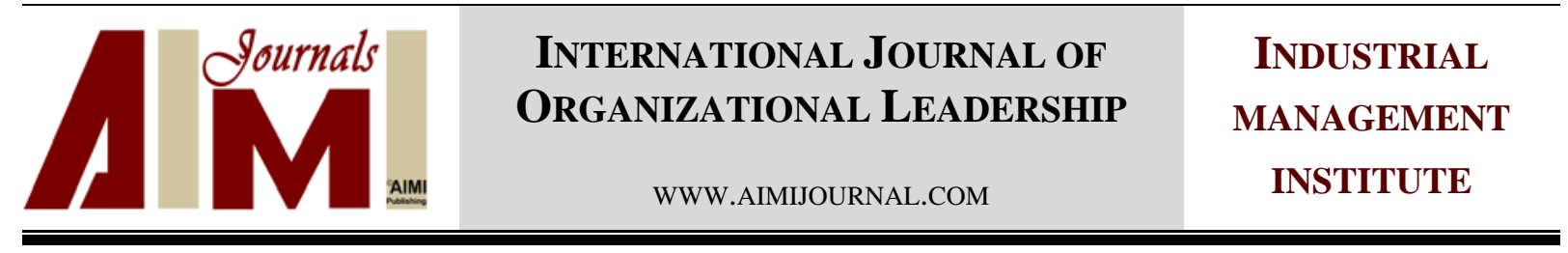

\title{
Identifying and prioritizing the indicators of talent management in recruiting radiology technicians
}

\author{
Sadegheh Hosseinzadeh Nojedeh \\ ${ }^{1}$ Department of Executive Management, Ardabil Science and Research Branch, Islamic Azad University, \\ Ardabil, Iran \\ ${ }^{2}$ Department of Executive Management, Ardabil Branch, Islamic Azad University, Ardabil, Iran
}

\begin{tabular}{ll}
\hline & ABSTRACT \\
\cline { 2 - 3 } & The purpose of this study was identifying and prioritizing the indicators of talent \\
management in recruiting the radiology technicians. The sample for the study was \\
Keywords: \\
Talent Management, \\
Indicators of Talent \\
Management, Radiology \\
Technicians
\end{tabular}$\quad \begin{aligned} & \text { the indicators of talent management, we employed multi-criteria decision-making techniques } \\
& \text { of TOPSIS method. Eight indicators were identified and prioritized using the TOPSIS } \\
& \text { method. These indicators are interest, commitment, skill, specialized knowledge, } \\
& \text { intelligence, the ability to solve the problem or issue, proper treatment with patient, and } \\
& \text { relationships with colleagues. The findings indicated that recruiting staff that do their work } \\
& \text { with love and are committed to the organization tend to be effective in improving hospital } \\
& \text { performance. }\end{aligned}$

(C)AIMI Journals

\section{Introduction}

Today, it is believed that human resources are the most important competitive advantage and capital of an organization. That is why the emphasis in the organization is on the valuable talents and their proper management is considered crucial. With the advent of words such as talent management we witness a paradigm shift from traditional human resources management to new human resources management which involves paying close attention to 
the organizational elite. The importance of this issue is also evident in the area of healthcare system.

Nowadays, human resources are the capital of organizations and it is argued that human beings are the survival of organizations in the competition (Armestrang, 2008). This means that organizations require human capital to function and accomplish their goals. Hospitals are one of the major organizations that individuals have significant role in their performance (Shahraky \& Mardani, 2010). Despite the considerable and undeniable improvements in the supply of science and technology, healthcare system still faces many challenges all over the world. Along with the emergence of large hospitals equipped with a variety of specialized units and with the extension of healthcare coverage, having talented and strong people are the main causes that lead to the success of hospitals. Due to this, in the field of human resources management the need for comprehensive talent management process design is emphasized (Schweyer, 2004).

Talent management encourages organizations to have right people with corresponding talents to right positions (Collings \& Mollahi, 2009). Talent management is a cycle which includes three main areas, namely identifying and recruiting talents, maintaining talents, and developing talents. Currently, organizations are not in search of recruitment of new members but they seek to attract talents which are known as battle of talents or war for talents (Michaels, Handfield-Jones, \& Axelord, 2001). Talent management in hospitals becomes more significant every day; because hospitals face difficulties due to the loss, retirement, or transfer of their skilled experts and with severe shortage of talents (Axelord, Hanfield, \& Michaels, 2002). Intense competition of diagnostic centers made it very difficult to maintain long-term competitive advantage. Following this, hospitals, based on the skills and talents of their employees, compete against one another and they know that by attracting and retaining the best and the most talented employees they can reach the highest profits and increase their value (Phillips \& Ropper, 2009).

It is worth noting that in talent management the fact that organizations consider some individuals with certain characteristics as a talent is of great importance. Since each organization has its own views and opinions about talent, so the definition of talent is a bit difficult and there is no universal and common definition of it. According to Michaels et al. (2001) various studies in different contexts have introduced diverse indicators as talent. Some people define talent as a collection of individual capabilities including skills, knowledge, and the capability of expansion and improvement. 
In another definition, talent refers to those with high potential ability or those with high performance. In this case, talents might possess specific skills or specialized knowledge that distinguish them from other employees and make their replacements extremely difficult (Gagné, 2007). Also, talent is defined as innate ability (Slizer \& Dowell, 2010) which involves individual differences (Transley, Turner, Carley, Harris, \& Sempik, 2007). Besides, talent is considered as knowledge and skill that is learnable, teachable, permanent, and incomparable (Ulrich \& Smallwood, 2013). Similarly, it is argued that talent is a property which leads to the creation of value in the organization and is defined as God-given power (Bukingham \& Vosburg, 2001) and ability and competence (Michaels et al., 2001). Table 1 represents terms commonly associated with talent in the literature and in different articles.

Table 1

Terms Commonly Associated with Talent in the Literature

\begin{tabular}{ll}
\hline Related terms & Resources \\
\hline Ability & $\begin{array}{l}\text { Gagné (2000), Hinrinchs (1966), Michaels et al. (2001), Slizer \& Dowell (2010), Tansley et al. (2006), } \\
\text { Williams (2000) }\end{array}$ \\
$\begin{array}{ll}\text { Capacity } \\
\text { Capability }\end{array}$ & Serico (2001) \\
Commitment & Ulrich (2007) \\
\hline $\begin{array}{l}\text { Competence/ Competency } \\
\text { Contribution }\end{array}$ & $\begin{array}{l}\text { Bathke-Langenegger (2012), Gonzalez- Cruz et al. (2009), Slizer \& Dowell (2010), Ulrich (2007), Williams } \\
\text { (2000) }\end{array}$ \\
\hline $\begin{array}{l}\text { Knowience } \\
\text { Performance }\end{array}$ & Chrich (2007) \\
\hline $\begin{array}{l}\text { Potential } \\
\text { Patterns of thought, feeling, al. (2008) } \\
\text { or behavior }\end{array}$ & Bathke-Langenegger (2012), Cheese et al. (2008), Michaels et al. (2001), Tansley et al. (2006) \\
\hline Skills & Stahl et al. (2007), Tanseley et al. (2007) \\
\hline
\end{tabular}

Given that the most important asset of any hospital is its medical team, hospitals should consider the most knowledgeable and well-informed individuals for this sector. They must identify the best people known as scientific talents and provide an opportunity for them to cooperate and join hospitals. It should be noted that management of pure talents and selection of superior individuals are of primary importance; otherwise, the applicants of medical team are abundant enough. Therefore, the choice of hospital staff, especially the right choice of radiology technicians who are in charge of diagnostic field is of primary importance. The identification of talent indicators in the selection of staff might be determined as the first step in implementation of talent team. The current study aimed to achieve the first step. The overall purpose of this study was the identifying and prioritizing the indicators of talent management in recruiting radiology technicians. This study, to our best knowledge, for the first time considered a specific group of radiology technicians and using multi-criteria 
decision-making techniques of TOPSIS method aimed to evaluate their talent indicators in hospitals. Consequently, the present study provided a practical example for hospital managers and health policy-makers. In this way, by identifying and prioritizing talent indicators, most appropriate interventions for improving hospital performance can be selected and executed.

\section{Methodology}

In the current study talent indicators were prioritized according to the radiology technicians' eligibility criteria and considering the opinions and judgments of managers and their sector personnel. The population for the study consisted of all managers and personnel of the radiology sector in Ardabil public hospitals and the samples for the study were drawn randomly. In research which are based on multi-criteria decision-making, because of the use of experts and selection of individuals who are qualified to judge in the relevant field, statistical sampling and traditional methods are not used. This means that statistical methods can be used only if the number of qualified people with the same condition such as expertise and experience is high.

Due to the small and limited number of people in the study population, only 30 people were selected as the population. This study was carried out through a survey method using questionnaire as the main instrument. First, a list of talent indicators obtained in various sciences was prepared (Gallardo-Gallardo, Dries, \& Gonzalez-cruz, 2013; Hartman, Feisel, \& Schober, 2010; Illes, Chuai, \& preece, 2010; Vural, Vardarlier, \& Aykir, 2012). Then, they were screened on the basis of their relevance to the activities of radiology technicians and experts and eight indicators including intelligence, interest, commitment, skill, specialized knowledge, relationships with colleagues, proper treatment with patient, and the ability to solve the problem or issue were identified.

To determine the performance criteria of radiology technicians, a questionnaire based on the professional qualification in nursing and the related fields were used. Among the listed items and after examining their connection with the performance of radiology technicians 14 factors were chosen. A questionnaire consisting of a matrix $(8 \times 14)$ was prepared and in each matrix talent management indicators were determined based on performance criteria of radiology technicians. The reliability of the questionnaire was assessed using Cronbach's alpha and the value of calculated alpha was 0.91 .

Having considered reliability, it is worth noting that the performance criteria and talent indicators that are used in this study were previously approved in various research and face 
and content validity of their translation were also examined (Cowan, Jenifer Wison-Barnett, Norman, \& Murrels, 2008; Gallardo-Gallardo, Dries, \& Gonzalez-cruz, 2013; Hartman, Feisel, \& Schober, 2010; Illes, Chuai, \& preece, 2010; Nilson et al., 2014; Vural, Vardarlier, \& Aykir, 2012). In addition, since this study used a ranking based on multi-criteria decisionmaking, judging in response was of primary importance and there was no need to calculate the other indicators of validity because they did not use statistical methods.

The questionnaires were completed by managers and personnel of radiology sector. In the next stage, the scale of the decision matrix was formed. Then, the weight of each criterion was calculated using the Shannon entropy and the final ranking was performed by TOPSIS method.

\section{Results}

Table 2 clearly indicates the frequency distribution of the number of participants in terms of gender, experience, and education.

Table 2

Frequency Distribution of Managers and Sector Authorities

\begin{tabular}{lcccccccc}
\hline & \multicolumn{2}{c}{ Sex } & \multicolumn{3}{c}{ Education } & \multicolumn{3}{c}{ Experience } \\
\hline Items & Male & Female & Associate Degree & Bachelor & MA Degree & $1-10$ Years & $11-20$ Years & $21-30$ Years \\
\cline { 2 - 10 } Number & 16 & 14 & 18 & 6 & 6 & 8 & 17 & 5 \\
Percent & 3.53 & 7.46 & 0.60 & 0.20 & 0.20 & 7.26 & 7.56 & 7.16 \\
\hline
\end{tabular}

Using the Shannon entropy, we weighted the identified criteria and in the next phase for ranking of options the multi-criteria decision-making techniques of TOPSIS method came into use. To determine the weight, the Shannon entropy was used and its theoretical basis is provided below. First, the value of $\mathrm{E}$ is calculated using the following equation:

Equation 1: $E \approx s\left\{P_{1}, P_{2}, \ldots P_{n}\right\}=k \sum_{i=1}^{n}\left[P_{i} \cdot \operatorname{Lnp} i\right]$

Where $\mathrm{k}$ is a positive constant. Then $\mathrm{P}$ value for every $\mathrm{i}$ and $\mathrm{j}$ is calculated using the following equation:

Equation 2: $P_{i j}=\frac{r_{i j}}{\sum_{i=1}^{m} r_{i j}} ; \forall i, j$

For $E_{j}$, a set in accordance with $P_{i j}$, we have the following formula:

Equation 3: $E_{j}=k \sum_{i=1}^{m}\left[P_{i j} \cdot \operatorname{Lnp} p_{i j}\right] ; \forall j$ 
So that $k=\frac{1}{L n m}$.

Then, the uncertainty and the degree of deviation of created data are calculated by the following formula:

Equation 4: $d_{j}=1-E_{j} ; \forall j$

For calculating $w_{j}$ weight of available indicators the following formula is used (for all $\mathbf{j}$ ):

Equation 5: $W_{j}=\frac{d_{j}}{\sum_{j=1}^{m} d_{j}} ; \forall j$

According to the procedures, the results of this method are presented in Table 3.

Table 3

Weight of Identified Criteria Using the Entropy Method

\begin{tabular}{clc}
\hline Row & & \multicolumn{1}{c}{ Criterion } \\
\hline 1 & Efforts to solve the problems of patients & 0.032 \\
2 & High quality and safe therapeutic and diagnostic care & 0.05 \\
3 & Satisfaction of the patients and clients with the services provided & 0.03 \\
4 & The use of medical equipment in accordance with the law and safety procedures & 0.12 \\
5 & The ability to learn tasks and technologies & 0.15 \\
6 & Carrying out tasks at a given time & 0.09 \\
7 & Observance of discipline in the workplace & 0.09 \\
8 & Following the procedures and rules of the organization with satisfaction & 0.11 \\
9 & Responsibility for activities and decisions & 0.06 \\
10 & Management of changes in the physical and mental state of the patients & 0.02 \\
11 & Documentation of services and the use of information technology & 0.10 \\
12 & The importance of maintaining the prestige and reputation of the organization & 0.04 \\
13 & Work and professional development & 0.02 \\
\hline
\end{tabular}

TOPSIS method was first introduced by Hwang and Yoon in 1981. In the analysis using the TOPSIS method decision matrix is needed. The rows of the matrix shows the options which are the indicators of talent management and the columns of the matrix represent the criteria for deciding in relation with the issue under review which are the performance criteria in this study. Table 4 shows the decision-making matrix of TOPSIS method and it exhibits the average of responses to each of the options based on criteria. The response to each question was specified as a number from 1 to 9 that was corresponded to the time range.

Table 4

Decision Matrix of TOPSIS Method

\begin{tabular}{|c|c|c|c|c|c|c|c|}
\hline Decision Matrix & $\begin{array}{l}\text { Efforts to } \\
\text { Solve } \\
\text { Problems }\end{array}$ & $\begin{array}{l}\text { Therapeutic and } \\
\text { Diagnostic Care }\end{array}$ & $\begin{array}{l}\text { Satisfaction of } \\
\text { the Patients and } \\
\text { Clients }\end{array}$ & $\begin{array}{l}\text { The Use of } \\
\text { Medical } \\
\text { Equipment }\end{array}$ & $\begin{array}{l}\text { The Ability to } \\
\text { Learn Tasks }\end{array}$ & $\begin{array}{l}\text { Carrying out } \\
\text { Tasks }\end{array}$ & $\begin{array}{l}\text { Observance of } \\
\text { Discipline }\end{array}$ \\
\hline Intelligence & 6.37 & 7.1 & 6.07 & 7.34 & 8.34 & 6.9 & 6.07 \\
\hline Interest & 8.1 & 7.7 & 7.54 & 7.24 & 8.07 & 7.74 & 7.84 \\
\hline Commitment & 8 & 7.94 & 7.94 & 7.6 & 7 & 8.2 & 8.3 \\
\hline Skill & 7.6 & 8.1 & 7.67 & 8.44 & 7.7 & 7.74 & 6.64 \\
\hline $\begin{array}{l}\text { Specialized } \\
\text { Knowledge }\end{array}$ & 7.14 & 8.04 & 7.14 & 8.24 & 7.94 & 7.04 & 5.64 \\
\hline Relationships with & 6.54 & 5.77 & 6.64 & 5.2 & 5.3 & 5.7 & 6.1 \\
\hline
\end{tabular}




\begin{tabular}{|c|c|c|c|c|c|c|c|}
\hline Colleagues & & & & & & & \\
\hline $\begin{array}{l}\text { Proper Treatment } \\
\text { with Patient }\end{array}$ & 7.67 & 6.5 & 8.04 & 5.64 & 4.87 & 5.27 & 6.14 \\
\hline $\begin{array}{l}\text { The Ability to } \\
\text { Solve the Problem } \\
\text { or Issue }\end{array}$ & 7.7 & 6.87 & 7.37 & 6.24 & 6.24 & 6.3 & 5.54 \\
\hline Decision Matrix & $\begin{array}{c}\text { Following the } \\
\text { Procedures and } \\
\text { Rules } \\
\end{array}$ & $\begin{array}{l}\text { Responsibility } \\
\text { for Activities }\end{array}$ & $\begin{array}{l}\text { Management of } \\
\text { Changes }\end{array}$ & $\begin{array}{c}\text { Documentation of } \\
\text { Services }\end{array}$ & $\begin{array}{l}\text { The Importance of } \\
\text { the Prestige of the } \\
\text { Organization }\end{array}$ & $\begin{array}{c}\text { Work and } \\
\text { Professional } \\
\text { Development }\end{array}$ & $\begin{array}{l}\text { Contribution to the } \\
\text { Improvement of } \\
\text { Working Environmer }\end{array}$ \\
\hline Intelligence & 6.04 & 6.5 & 7.67 & 7.57 & 5.94 & 7.34 & 6.8 \\
\hline Interest & 7.94 & 7.97 & 7.27 & 7.54 & 7.7 & 7.94 & 8.1 \\
\hline Commitment & 8.44 & 8.4 & 7.57 & 7.7 & 8.3 & 7.7 & 8.04 \\
\hline Skill & 6.37 & 7.04 & 7.94 & 8.07 & 6.8 & 7.8 & 7.4 \\
\hline $\begin{array}{l}\text { Specialized } \\
\text { Knowledge }\end{array}$ & 5.97 & 6.5 & 7.64 & 8.07 & 6.37 & 7.9 & 6.9 \\
\hline $\begin{array}{l}\text { Relationships } \\
\text { with Colleagues }\end{array}$ & 5.87 & 6.04 & 6.17 & 5.7 & 6.64 & 6.5 & 7.84 \\
\hline $\begin{array}{l}\text { Proper } \\
\text { Treatment with } \\
\text { Patient }\end{array}$ & 5.54 & 6.24 & 7.8 & 5.27 & 7.27 & 6.64 & 6.67 \\
\hline $\begin{array}{l}\text { The Ability to } \\
\text { Solve the } \\
\text { Problem or Issue }\end{array}$ & 5.7 & 6.44 & 7.57 & 6.17 & 6.9 & 7.14 & 7.5 \\
\hline
\end{tabular}

The output of TOPSIS method for normalized matrix can be seen in Table 5 .

Table 5

Normalized Decision Matrix

\begin{tabular}{|c|c|c|c|c|c|c|c|}
\hline $\begin{array}{l}\text { Normalized } \\
\text { Matrix }\end{array}$ & $\begin{array}{l}\text { Efforts to } \\
\text { Solve } \\
\text { Problems }\end{array}$ & $\begin{array}{l}\text { Therapeutic and } \\
\text { Diagnostic Care }\end{array}$ & $\begin{array}{l}\text { Satisfaction of } \\
\text { the Patients and } \\
\text { Clients }\end{array}$ & $\begin{array}{l}\text { The Use of } \\
\text { Medical } \\
\text { Equipment }\end{array}$ & $\begin{array}{l}\text { The Ability to } \\
\text { Learn Tasks }\end{array}$ & $\begin{array}{l}\text { Carrying out } \\
\text { Tasks }\end{array}$ & $\begin{array}{l}\text { Observance of } \\
\text { Discipline }\end{array}$ \\
\hline Intelligence & 0.304 & 0.344 & 0.293 & 0.367 & 0.419 & 0.354 & 0.325 \\
\hline Interest & 0.386 & 0.373 & 0.364 & 0.362 & 0.405 & 0.397 & 0.420 \\
\hline Commitment & 0.381 & 0.385 & 0.383 & 0.380 & 0.351 & 0.421 & 0.444 \\
\hline Skill & 0.362 & 0.393 & 0.370 & 0.421 & 0.387 & 0.383 & 0.356 \\
\hline $\begin{array}{l}\text { Specialized } \\
\text { Knowledge }\end{array}$ & 0.340 & 0.390 & 0.344 & 0.412 & 0.399 & 0.361 & 0.302 \\
\hline $\begin{array}{l}\text { Relationships with } \\
\text { Colleagues }\end{array}$ & 0.312 & 0.280 & 0.320 & 0.260 & 0.266 & 0.292 & 0.327 \\
\hline $\begin{array}{l}\text { Proper Treatment } \\
\text { with Patient }\end{array}$ & 0.366 & 0.315 & 0.388 & 0.282 & 0.244 & 0.270 & 0.329 \\
\hline $\begin{array}{l}\text { The Ability to } \\
\text { Solve the Problem } \\
\text { or Issue }\end{array}$ & 0.367 & 0.333 & 0.356 & 0.312 & 0.313 & 0.323 & 0.297 \\
\hline $\begin{array}{l}\text { Normalized } \\
\text { Matrix }\end{array}$ & $\begin{array}{l}\text { Following the } \\
\text { Procedures and } \\
\text { Rules }\end{array}$ & $\begin{array}{l}\text { Responsibility } \\
\text { for Activities }\end{array}$ & $\begin{array}{l}\text { Management of } \\
\text { Changes }\end{array}$ & $\begin{array}{l}\text { Documentation of } \\
\text { Services }\end{array}$ & $\begin{array}{l}\text { The Importance of } \\
\text { the Prestige of the } \\
\text { Organization }\end{array}$ & $\begin{array}{l}\text { Work and } \\
\text { Professional } \\
\text { Development } \\
\end{array}$ & $\begin{array}{l}\text { Contribution to the } \\
\text { Improvement of } \\
\text { Working Environmen } \\
\end{array}$ \\
\hline Intelligence & 0.325 & 0.331 & 0.363 & 0.378 & 0.299 & 0.351 & 0.324 \\
\hline Interest & 0.428 & 0.406 & 0.344 & 0.376 & 0.388 & 0.380 & 0.386 \\
\hline Commitment & 0.455 & 0.428 & 0.358 & 0.384 & 0.418 & 0.368 & 0.383 \\
\hline Skill & 0.343 & 0.359 & 0.376 & 0.402 & 0.342 & 0.373 & 0.352 \\
\hline $\begin{array}{l}\text { Specialized } \\
\text { Knowledge }\end{array}$ & 0.322 & 0.331 & 0.362 & 0.402 & 0.321 & 0.378 & 0.329 \\
\hline $\begin{array}{l}\text { Relationships with } \\
\text { Colleagues }\end{array}$ & 0.316 & 0.308 & 0.292 & 0.284 & 0.334 & 0.311 & 0.373 \\
\hline $\begin{array}{l}\text { Proper Treatment } \\
\text { with Patient }\end{array}$ & 0.298 & 0.318 & 0.369 & 0.263 & 0.366 & 0.318 & 0.318 \\
\hline $\begin{array}{l}\text { The Ability to } \\
\text { Solve the Problem } \\
\text { or Issue }\end{array}$ & 0.307 & 0.328 & 0.358 & 0.308 & 0.347 & 0.342 & 0.357 \\
\hline
\end{tabular}

Table 6 represents the weighted normalized matrix and the weight of each indicator is calculated using the Shannon entropy. 
Table 6

Weighted Normalized Matrix

\begin{tabular}{|c|c|c|c|c|c|c|c|}
\hline $\begin{array}{l}\text { Weighted } \\
\text { Normalized } \\
\text { Matrix }\end{array}$ & $\begin{array}{l}\text { Efforts to } \\
\text { Solve } \\
\text { Problems }\end{array}$ & $\begin{array}{l}\text { Therapeutic and } \\
\text { Diagnostic Care }\end{array}$ & $\begin{array}{l}\text { Satisfaction of } \\
\text { the Patients and } \\
\text { Clients }\end{array}$ & $\begin{array}{l}\text { The Use of } \\
\text { Medical } \\
\text { Equipment }\end{array}$ & $\begin{array}{l}\text { The Ability to } \\
\text { Learn Tasks }\end{array}$ & $\begin{array}{l}\text { Carrying out } \\
\text { Tasks }\end{array}$ & $\begin{array}{l}\text { Observance of } \\
\text { Discipline }\end{array}$ \\
\hline Intelligence & 0.010 & 0.020 & 0.010 & 0.045 & 0.066 & 0.033 & 0.031 \\
\hline Interest & 0.013 & 0.021 & 0.013 & 0.044 & 0.064 & 0.037 & 0.041 \\
\hline Commitment & 0.012 & 0.022 & 0.014 & 0.046 & 0.056 & 0.039 & 0.043 \\
\hline Skill & 0.012 & 0.022 & 0.013 & 0.052 & 0.061 & 0.036 & 0.034 \\
\hline $\begin{array}{l}\text { Specialized } \\
\text { Knowledge }\end{array}$ & 0.011 & 0.022 & 0.012 & 0.050 & 0.063 & 0.034 & 0.029 \\
\hline $\begin{array}{l}\text { Relationships with } \\
\text { Colleagues }\end{array}$ & 0.010 & 0.016 & 0.011 & 0.032 & 0.042 & 0.027 & 0.032 \\
\hline $\begin{array}{l}\text { Proper Treatment } \\
\text { with Patient }\end{array}$ & 0.012 & 0.018 & 0.014 & 0.034 & 0.039 & 0.025 & 0.032 \\
\hline $\begin{array}{l}\text { The Ability to } \\
\text { Solve the Problem } \\
\text { or Issue }\end{array}$ & 0.012 & 0.019 & 0.013 & 0.038 & 0.050 & 0.030 & 0.029 \\
\hline $\begin{array}{l}\text { Weighted } \\
\text { Normalized } \\
\text { Matrix }\end{array}$ & $\begin{array}{l}\text { Following the } \\
\text { Procedures and } \\
\text { Rules }\end{array}$ & $\begin{array}{l}\text { Responsibility } \\
\text { for Activities }\end{array}$ & $\begin{array}{l}\text { Management of } \\
\text { Changes }\end{array}$ & $\begin{array}{l}\text { Documentation of } \\
\text { Services }\end{array}$ & $\begin{array}{l}\text { The Importance of } \\
\text { the Prestige of the } \\
\text { Organization }\end{array}$ & $\begin{array}{l}\text { Work and } \\
\text { Professional } \\
\text { Development }\end{array}$ & $\begin{array}{l}\text { Contribution to the } \\
\text { Improvement of } \\
\text { Working Environmen }\end{array}$ \\
\hline Intelligence & 0.036 & 0.021 & 0.009 & 0.041 & 0.014 & 0.009 & 0.008 \\
\hline Interest & 0.048 & 0.025 & 0.008 & 0.041 & 0.018 & 0.009 & 0.009 \\
\hline Commitment & 0.051 & 0.027 & 0.009 & 0.042 & 0.020 & 0.009 & 0.009 \\
\hline Skill & 0.038 & 0.022 & 0.009 & 0.044 & 0.016 & 0.009 & 0.009 \\
\hline $\begin{array}{l}\text { Specialized } \\
\text { Knowledge }\end{array}$ & 0.036 & 0.021 & 0.009 & 0.044 & 0.015 & 0.009 & 0.008 \\
\hline $\begin{array}{l}\text { Relationships with } \\
\text { Colleagues }\end{array}$ & 0.035 & 0.019 & 0.007 & 0.031 & 0.016 & 0.008 & 0.009 \\
\hline $\begin{array}{l}\text { Proper Treatment } \\
\text { with Patient }\end{array}$ & 0.033 & 0.020 & 0.009 & 0.029 & 0.017 & 0.008 & 0.008 \\
\hline $\begin{array}{l}\text { The Ability to } \\
\text { Solve the Problem } \\
\text { or Issue }\end{array}$ & 0.034 & 0.020 & 0.009 & 0.034 & 0.017 & 0.009 & 0.009 \\
\hline
\end{tabular}

The amount of positive and negative ideal for this decision-making position is shown in Table 7.

Table 7

Positive and Negative Ideals

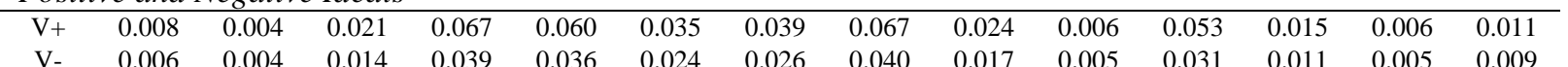

\begin{tabular}{lllllllllllllll}
$\mathrm{V}-$ & 0.006 & 0.004 & 0.014 & 0.039 & 0.036 & 0.024 & 0.026 & 0.040 & 0.017 & 0.005 & 0.031 & 0.011 & 0.005 & 0.009 \\
\hline
\end{tabular}

The output of TOPSIS method by setting the positive and negative ideals and by determining the ranking is shown in Table 8.

Table 8

Final Results of TOPSIS Technique

\begin{tabular}{|c|c|c|c|c|c|}
\hline Row & \begin{tabular}{|cc} 
Calculation of Distances \\
\end{tabular} & $d^{+}{ }_{i}$ & $d^{-} i$ & $c l_{i}^{+}$ & Rank \\
\hline $\mathrm{A}_{1}$ & Intelligence & 0.02305 & 0.0344 & 0.5989 & 5 \\
\hline $\mathrm{A}_{2}$ & Interest & 0.00963 & 0.0394 & 0.8035 & 1 \\
\hline $\mathrm{A}_{3}$ & Commitment & 0.01200 & 0.0391 & 0.7652 & 2 \\
\hline $\mathrm{A}_{4}$ & Skill & 0.01735 & 0.0370 & 0.06811 & 3 \\
\hline $\mathrm{A}_{5}$ & Specialized Knowledge & 0.02276 & 0.0361 & 0.6134 & 4 \\
\hline $\mathrm{A}_{6}$ & Relationships with Colleagues & 0.04225 & 0.0063 & 0.1294 & 8 \\
\hline $\mathrm{A}_{7}$ & Proper Treatment with Patient & 0.04460 & 0.0071 & 0.1375 & 7 \\
\hline $\mathrm{A}_{8}$ & The Ability to Solve the Problem or Issue & 0.03450 & 0.0154 & 0.3087 & 6 \\
\hline
\end{tabular}

Therefore, the prioritizations of the indicators of talent management are rated from one to eighth as follows:

$$
A_{2}>A_{3}>A_{4}>A_{5}>A_{1}>A_{8}>A_{7}>A_{6}
$$




\section{Discussion}

Prioritization results of TOPSIS method showed that interest and commitment were placed at the first and second level, respectively. This highlights that the choice of people according to their interest and developing a structure for determining the interest and commitment of technicians can have a greater impact on the performance and consequently on the achievement of organizational goals and accomplishment of individual goals (Buchan, Parkin, \& Sochalski, 2001). Also, using radiology technicians in different positions commensurate with their interest and abilities can lead to the promotion of hospital performance (Kane et al., 2007). Skill, specialized knowledge, intelligence, and the ability to solve the problem or issue, with a slight difference, were placed at the third, fourth, fifth, and sixth level, respectively.

In addition, proper treatment with patient and relationships with colleagues were placed at the two end positions. The final indicator, proper treatment with patient, because of the low direct contact of radiology technicians with patients can be justified. From the managers' perspective, the least importance referred to relationships with colleagues who can be explained in greater detail by examining the formal and informal relationships and by considering the concentration and decentralization of the organization.

This study would help the senior managers to identify differences by comparing the status quo and comparing it with ideal situation. Then, based on these differences and examining their causes, they would determine and implement the optimized solutions for the current solution. For instance, by taking into account the job cycle of radiology technicians since colleges admissions, their professional education and training, and finally recruiting them in medical diagnostic centers it could be concluded that related topics to talent in all processes of this cycle is of importance. The crucial point is that the talent management as a new management system should be used during each process of recruiting, retaining, and developing of radiology technicians.

\section{Conclusion}

Through the centuries, many organizations tried to use talent management and yet it remains a distinct possibility which does not have a clear framework. Given that one of the main areas of health development in societies is health sector which is directly related to human health, the choice of hospital staff, especially the right choice of radiology technicians who are responsible for diagnostic field plays an important role. The purpose of this study was 
identifying and prioritizing the indicators of talent management in recruiting the radiology technicians and choosing right people with remarkable skills to right position and contribute to the public health promotion and service quality improvement for patients. Results showed that interest and commitment were placed at the first and second level, respectively. So, it could be stated that the choice of people according to their interest would lead to employees' long-term commitment. Also, recruiting staff that do their work with love and are committed to the organization tend to be effective in improving hospital performance. Skill, specialized knowledge, intelligence, and the ability to solve the problem or issue, with a slight difference, were placed at the third, fourth, fifth, and sixth level, respectively. In addition, proper treatment with patient and relationships with colleagues were placed at the two end positions.

According to the results, healthcare system managers to achieve their goals need employees who do their work in a very strong sense and are committed to the organization; to establish and maintain these characteristics in employees, appropriate context should be provided in the organization. This consideration implies that if organization does not acquire and develop the necessary talent, those characteristics will fail and investments will not earn desired return. Using the talent management system in the healthcare system, the clinical skills of medical team would improve and the job satisfaction of employees would increase. In addition, recruitment of new members and retaining potential and skilled employees would be possible; it would provide opportunities to learn and improve skills and prevent the transmission and turnover of potential staff. Consequently, it would increase organizational productivity such as high quality treatment of patients and accurate diagnosis of diseases.

The radiology sector is considered as part of Para-clinic and outpatient departments of hospitals, so for determining and prioritizing the indicators of talent, wider research should be carried out in other parts of the treatment area. Significant attention was paid to the radiology technicians but not to other staff that could provide additional useful information and would require a bigger sample. This highlights that if the current research would be applied to the respondents from another sector, the results might be different than the current results. Employees, even high potential individuals, often tend to be naive, and somewhat reactive, when it comes to managing their own careers. Advances in talent management may assist both organizations and individual employees to be aware of how strategic talent management decisions may or may not influence them. The findings need to be illuminated carefully and with caution in regard to generalizability. The relatively small sample size represents a main 
limitation. Future studies should preferably draw from larger and more representative samples, permitting the results to be more generalizable.

\section{References}

Armestrang, M. (2008). Strategic human resource management (4 ${ }^{\text {th }}$ ed.). London: Kogan Page.

Axelord B, Handfield, H., \& Michaels, E. (2002). A new game plan for C players. Harvard Business Review, 80(1), 80-88.

Bethke-Langenegger, P. (2012). The differentiated workforce: Effects of categorization in talent management on workforce level. Unpublished working paper, 18. Switzerland: Department of Business Administration, University of Zurich.

Buchan, J, Parkin, T., \& Schalski, J. (2003). International nurse mobility: Trends and policy implications. Geneva: World Health Organization, International Council of Nurses and Royal College of Nursing.

Buckingham, M., \& Vosburgh, R. (2001). The 21st century resources function: It’s the talent, stupid! Human Resource Planning. 24(4), 17-23.

Cheese, P., Thomas, R. T., \& Craig, E. (2008). The talent powered organization: Strategies for globalization, talent management and high performance. London: Kogan Page.

Collings, D. G., \& Mollahi, K. (2009). Strategic talent management: A review and research agenda. Human Resource Management Review, 19(4), 304-313.

Cowan, D., Jenifer Wilson-Barnett, D., Norman, I. J., \& Murrels, T. (2008). Measuring nursing competence: Development of a self-assessment tool for general nurses across Europe. International Journal of Nursing Studies, 45(6), 902-913.

Gagné, F. (2000). International handbook of giftedness and talent ( $2^{\text {nd }}$ ed.). Oxford: Elsevier Science.

Gagné, F. (2007). Ten commandments for academic talent development. Gifted Child Quarterly, 51(2), 93-118.

Gallardo-Gallardo, E., Dries, N., \& Gonzalez-Cruz, T. (2013). What is the meaning of "talent" in the world of work? Human Resource Management Review, 23(14), 290-300.

González-Cruz, T., Martínez-Fuentes, C., \& Pardo-del-Val, M. (2009). Talent management in Spanish industry. Economía Industrial, 374, 21-35.

Hartman, E., Feisel, E., \& Schober, H. (2010). Talent management of Western MNCs in China: Balancing global integration and local responsiveness. Journal of World Business, 45(2), 169-178.

Hinrichs, J. R. (1966). High-talent personnel: Managing a critical resource. Vermont: American Management Association.

Illes, P., Chuai, X., \& Preece, D. (2010). Talent Management and HRM in Multinational companies in Beijing: Definitions, differences and drivers. Journal of World Business, 45(2), 179-189.

Jericó, P. (2001). La gestión del talento: Enfoque conceptual y empírico. Boletín de Estudios Económicos, LVI, 174, 423441.

Kane, R. L, Shamliyan, T. A, Muller, C., Duval, S., \& Wilt, T. J. (2007). The association of registered nurse staffing levels and patient outcomes: Systematic review and meta-analysis. Medical Care, 45(12), 1195-1204.

Michaels, E., Handfield-Jones, H., \& Axelord, B. (2001). The war for talent. Boston: Harvard Business School Publishing.

Nilsson, J., Johansson, E., Egmar, A., Florin, J., Lekshel, J., Lepp, M.,...Gardulf, A. (2014). Development and validation of a new tool measuring nurses self-reported professional competence. The Nurses professional competence (NPC) scale. Journal of Nurse Education Today, 34(4), 574-580.

Phillips, R., \& Ropper, O. (2009). A framework for talent management in real state. Journal of Corporate Real Estate, 11(1), $7-16$.

Schweyer, A. (2004). Talent management systems: Best practices in solutions for recruitment, retention, and work force planning. New York, NY: John Wiley and Sons.

Shahraky, A., \& Mardani, M. (2010). Relationship between hospital personnel's personality characteristics and organizational climate. Journal of Health Administration. 12(38), 23-30.

Slizer, R., \& Dowell, B. (2010). Strategy-driven talent management: A leadership imperative. San Francisco: John Wiley and Sons.

Stahl, G. K., Björkman, I., Farndale, E., Morris, S. S., Paauwe, J., Stiles, P.,...Wright, P. M. (2007). Global talent management: How leading multinationals build and sustain their talent pipeline. INSEAD Faculty \& Research Working Papers. 
Tansley, C., Harris, L., Stewart, J., \& Turner, P. (2006). Talent management: Understanding the dimensions. London: Chartered Institute of Personnel and Development (CIPD).

Tansley, C., Turner, P., Carley, F., Harris, L., Sempik, A. (2007). Talent: Strategy, management, measurement. London: Chartered Institute of Personnel and Development (CIPD).

Ulrich, D., \& Smallwood, N. (2013). What is talent? Leader to Leader. 63, 55-61.

Vural, Y., Vardarlier, P., \& Aykir, A. (2012). The effects of using talent management with performance evaluation system over employee Commitment. Journal of Procedia-Social \& behavioral sciences, 58, 340-349.

Williams, M. (2000). The war for talent: Getting the best from the best. London: Chartered Institute of Personnel \& Development (CIPD). 